\title{
Evaluation of the relationship between philosophical mindset and doing managerial tasks
}

\author{
Kioumars Niazazari, Soheila Khosroabadi ${ }^{\star}$ \\ Educational Administration of sari branch , Islamic Azad University of sari, Sri, Iran \\ *E-mail adress: soheilakhosroabadi@yahoo.com
}

\begin{abstract}
Evaluation of the relationship between the philosophical mindset of managers and their managerial components in secondary schools of the BOJNURD city in year 2012-2013, was the main aim of this paper. This study given to the nature of relevant subject and purposes of this study is descriptive - correlation. Statistical Population is all managers of secondary schools of the BOJNURD city, all Statistical Population were used in collecting information $(\mathrm{n}=70)$. Data collection tool was two questionnaires included a questionnaire with 60 questions about the philosophical mindset which has examined comprehensiveness, depth and flexibility and other questionnaire was SOCIOMETRIC questionnaire which Managers tasks in five categories of planning, organizing, coordinating, evaluating and staff morale was measured, this questionnaire was developed as a teacher questionnaire. Questionnaire based on CRONBACH'S alpha was approved. The results show that there is a significant relationship between the philosophical mind Directors of managers with their performance in return for their management tasks. Also, between gender of managers and their education was not observed a significant difference.
\end{abstract}

Keywords: management skills; perceptual skills; human skills; philosophical mindset

\section{INTRODUCTION}

Need to manage in all social areas is critical and tangible. This need in the educational systems that have fundamental role in circulating in the community and its continuity and survival, is more important. Similarly, philosophy mindset is one of the features that can help managers when faced with numerous issues in education. In other words, a manager who has high philosophical mindset, for facing issues based on long-term goals, Creative generalized, Underlying rationale and a wide range of reasonable choices, has more chances. A person with philosophically mindset person has characteristics that can be grouping them: Universality, Meditation and flexibility. This person always tries to universalize ideas, sees Issues associated with broad area and long-term goals, he asks about obviously affairs, and to move beyond personal prejudice, ignorance and prejudice and stereotype, adds to his has chances. The person is flexible, foresight and creative. He examines issues from various aspects (Smith, 1995). According to management definition that is direction of activities of people toward specific goals, for a director who could handle management tasks and propel collective actions to a predetermined objective, he must have special skills. Management skills are among issues that have been important since the beginning management issues and have been addressed in various ways. This study is based on this issue, in order to get how are 
skills of managers (at different levels), and how is its relations with social factors? It is obvious that among the types of management, management on education organizations is the most important, because on the one hand, its result is become crude human into creative human, on the one other hand, it is supplier of manpower needs of society at different levels and in different sectors of cultural, social and economic. (Abu TORABI, 2008). Kant says about the importance of it: Education is one of the largest and most difficult issues related to human, evident that the variety of educational management is important and has special place. Educational management is facing horizons beyond economic principles and tool objectives, Although these standards or criteria are not tangible and measurable, but are important about Happiness of individuals, organizations, communities, improving products and services. These areas include high levels of mindset and the conceptual tools such as thought, Intellection and intuition that can by them to explain accuracy of the relationship. Thinking and right-thinking skills are among critical issues that have long occupied the minds of thinkers. Thinking is one of the fundamental issues of education that the necessary tools are required to develop it, one of these tools having a philosophic mind that helps people in proper and logical thinking (AMIRTASH 2011). Philosophical mindset is a tool to assist administrators who have Universality, Meditation and flexibility in their thinking. And it is expected that other directors have different qualities in their decisions. Philosophical mindset enables managers to have minimum error in your organizational decisions and better understand the subtleties and make reasonable and good combination. A person has philosophical mindset, has special human traits in three dimensions of Universality, Meditation and flexibility. Philosophical mindset finally helps to strengthen the cognitive skills of managers and indeed lead to the philosophical action. Smith believes it is important for managers have philosophically mindset, the mind of managers must have three dimensions of Universality, Meditation and flexibility. Dewey says: philosophy mindset the same as the spirit of philosophical is the features that deal with deep issues is comprehensive and flexible. MIRKAMALI believes about philosophical mind: Logical thinking is basis of manager task, the manager shall with logical thinking tries to identify the problems and find solutions for the problem, this is not possible, unless he has characteristic of Logical thinking. Logical thinking is result of having the philosophy mind. BEHRANGI believes that a manager with having a philosophical mindset has power discipline issues for effectiveness and quality efficiency. SHARIATMADARI also believes that characteristic of the spirit of philosophy (logical thinking) are: 1-reasonable doubt, 2-curiosity, 3-Thoughtfulness 4-wide viewing 5- mindedness 6- progressive ambitions 7- unity of character 8 - Adherence to values. Smith about the importance of having a philosophical mind for managers says: Forming Specific nature, certain behavioral traits in a manager is so important in complex organizations such as education organizations. Manager skills in each organization effect on effectiveness of organization and lead to improve its performance. Experts know three types of skills required of managers: technical, human and conceptual. Parsons argues that organizations can be considered as a system. Parsons distinguishes three levels of the organization, which include institutional level, management level and technical level.

- At the institutional level, providing harmonized between the organization and the larger society constitutes the main function. Any enterprise which is engaged in activities that is important to society as a whole. Aims and values of the organization must be consistent with community values. Establish coordination is of the task body institutional level.

- At management Level, Major responsibility includes: Corporate governance and providing raw materials required technical level. The organizational level acts as an intermediary 
between technical systems and customers, or clients of the organization. At this level, essentially Administration Visitors, enforcers are present.

- At technical level, the vague goals of the organization convert activities that are planned to achieving the purpose. Relying on two main previous issues can be paid in two-dimensional analysis in organizations which are summarized in Figure 1.

Generally, the organizational levels require human skills the same, while the institutional level managers need more perceptual skills than the technical level managers. Conversely, technical level managers need more technical skills than institutional level managers. In other words, the technical skills are reduced with increasing organizational levels (from top to bottom) and contrast cognitive skills are reduced increasing organizational levels. Perceptual skills can be known as a tool to assist people in the process of rational thinking. It is obvious that, philosophy in addition to Field of study can provide a way. Philosophical thinking is able to increase perceptual abilities of managers and make unity between thought and action. Thus, given to the importance this issue, this research tries to evaluate the impacts of the philosophical thinking of managers and its impact on doing managerial tasks of managers of secondary schools of the BOJNURD city.

\section{Research questions}

1. Is there a significant difference between philosophically mindset of male and female managers in three levels of education?

2. Is there a significant relationship between the philosophical mindset aspects and doing their management tasks?

\section{Community and Statistical sample:}

The statistical population of this research is managers of secondary school of BOJNURD city that the total population of 70 people was estimated. Due to the low population of community, all managers were used as a study sample and 70 questionnaires were distributed.

\section{Data collection tools:}

To collect data from a statistic sample and in order to test the hypotheses of this study, according to variables of the research, two questionnaires have been used.

1 - The research questionnaire consisted of two questions. The first category is related to statistic sample characteristics in terms of gender, age, marital status, education level and Military Service, the second category is used includes questions based on the philosophy mindset related to theory of Philip J. Smith. This part contains the questionnaire with 60 questions.

2 - SOCIOMETRY Questionnaire of doing management tasks: Questionnaire was prepared as teacher questionnaires and managers tasks was measured in five categories of functions of planning, organizing, coordinating, and evaluating, staff morale.

\section{Validity and reliability of data collection}

In the present study, the validity of the data collection has been approved by the validity or symbol validity. For the reliability test of questionnaire, the CRONBACH Alpha was used. Based on this approach by Preliminary Study about 35 managers of statistical population and 
using software SPSS, the reliability of questionnaire of philosophical mindset 0.736 , and questionnaire of doing management tasks 0.982 are obtained.

Table 1. Reliability of questionnaire and related issues to it.

\begin{tabular}{|c|c|c|c|c|c|}
\hline $\begin{array}{c}\text { Philosophical } \\
\text { mind }\end{array}$ & Universality & \multicolumn{2}{|c|}{ Pondering } & \multicolumn{2}{c|}{ Flexibility } \\
\hline 0.73 & $0 / 75$ & \multicolumn{2}{|c|}{$0 / 79$} & \multicolumn{2}{c|}{$0 / 71$} \\
\hline $\begin{array}{c}\text { Performing } \\
\text { administrative } \\
\text { tasks }\end{array}$ & Planning & Organizing & Coordination & $\begin{array}{c}\text { Attention } \\
\text { to staff } \\
\text { morale }\end{array}$ & Evaluation \\
\hline 0.98 & $0 / 93$ & $0 / 91$ & $0 / 94$ & $0 / 93$ & $0 / 94$ \\
\hline
\end{tabular}

\section{Research findings}

The first research question: Is there a significant difference between philosophically mindset of male and female managers of secondary schools?

There is a significant difference between Philosophical mindset and doing managerial tasks in men and women managers: $\mathrm{H} 1$

There is not a significant difference between Philosophical mindset and doing managerial tasks in men and women managers: $\mathrm{H} 0$

Table 2. Results of t-test related to philosophical mindset and doing management tasks according to gender.

\begin{tabular}{|c|c|c|c|c|c|c|c|}
\hline $\begin{array}{c}\text { Significance } \\
\text { level }\end{array}$ & $\begin{array}{c}\text { Degree } \\
\text { of } \\
\text { freedom }\end{array}$ & $\begin{array}{c}\mathrm{T} \\
\text { value }\end{array}$ & $\begin{array}{c}\text { Standard } \\
\text { deviation }\end{array}$ & Mean & Number & Sex & \\
\hline $0 / 66$ & 68 & $0 / 43$ & $11 / 30$ & $107 / 7$ & 35 & Female & Philosophical \\
\cline { 4 - 7 } & & $13 / 49$ & $106 / 4$ & 35 & Male & mind \\
\hline \multirow{2}{*}{$0 / 98$} & 68 & $0 / 02$ & $23 / 75$ & $121 / 6$ & 35 & Male & $\begin{array}{c}\text { Performing } \\
\text { administrative } \\
\text { tasks }\end{array}$ \\
\hline
\end{tabular}

As can be seen in Table 1, significant level of t-test to compare the philosophical mindset of male and female managers is 0.66 and this level is larger than 0.5 that is the minimum significant level, significant differences between male and female managers in terms of the philosophical mindset, is not confirmed. It means the hypothesis $\mathrm{H} 0$ is Confirmed and $\mathrm{H} 1$ is rejected. Also significant level of t-test to compare doing managerial tasks is 0.98 , which is larger than the significance level minimum 0.05 . It shows there is no significant difference between male and female managers in doing managerial tasks. 
Table 3. Results of t-test related to philosophical mindset and doing management tasks according to education degree.

\begin{tabular}{|c|c|c|c|c|c|c|c|}
\hline $\begin{array}{c}\text { Significance } \\
\text { level }\end{array}$ & $\begin{array}{c}\text { Degree } \\
\text { of } \\
\text { freedom }\end{array}$ & $\begin{array}{c}\text { T } \\
\text { value }\end{array}$ & $\begin{array}{c}\text { Standard } \\
\text { deviation }\end{array}$ & Mean & Number & degree & \\
\hline $0 / 97$ & 68 & $-0 / 03$ & $12 / 79$ & $107 / 0$ & 60 & BA & Philosophical \\
\cline { 4 - 7 } & & $10 / 07$ & $107 / 2$ & 10 & MA & mind \\
\hline \multirow{2}{*}{$0 / 82$} & 68 & $-0 / 22$ & $28 / 77$ & $123 / 2$ & 10 & MA & $\begin{array}{c}\text { Performing } \\
\text { administrative } \\
\text { tasks }\end{array}$ \\
\hline
\end{tabular}

As can be seen in Table 2, significant level of t-test to compare the impact of education degree on their philosophical mindset and doing management tasks of male and female managers is estimated 0.97 and 0.82 that given to minimum significant level, 0.05 , there is no significant difference between managers education levels related to their philosophical mindset and their doing management tasks.

Second research question: Is there relation between the philosophical mindset of managers and doing management tasks?

There is a significant difference between Philosophical mindset of managers and their doing management tasks: H1

There is not a significant difference between Philosophical mindset of managers and their doing management tasks: $\mathrm{H} 0$

Table 4. Correlation Test Results between philosophical mindset and doing management tasks and its components.

\begin{tabular}{|c|c|c|c|c|c|c|c|}
\hline Evaluation & Morale & \multicolumn{2}{|c|}{ Coordination } & Organizing & Planning & Performing & \\
\hline $0 / 220$ & $0 / 216$ & $0 / 835^{* *}$ & $0 / 235^{*}$ & $0 / 258^{*}$ & $0 / 246^{*}$ & $\begin{array}{c}\text { The correlation } \\
\text { coefficient }\end{array}$ & $\begin{array}{l}\text { Philosophical } \\
\text { mind }\end{array}$ \\
\hline $0 / 067$ & $0 / 072$ & $0 / 000$ & $0 / 05$ & $0 / 031$ & $0 / 040$ & Significance & \\
\hline 70 & 70 & 70 & 70 & 70 & 70 & Number & \\
\hline
\end{tabular}

* Significance at $95 \%$

** Significance at $99 \%$

The above table shows that the correlation coefficient between the philosophical mindset with doing administrative tasks is equal to $\mathrm{r}=0.246$ that is larger than critical value of table at level 95\% (0.232), that shows there is a significant difference at level $95 \%(p<0.05)$. Thus, we can conclude that there is a significant and direct relationship between philosophically mindset and their doing administrative tasks. If philosophical mindset of managers is higher, the rate of their doing administrative tasks also is higher. In addition, the correlation results of philosophical mindset with the five categories of management tasks, suggest that the correlation coefficient between philosophical mindset with Coordination is $\mathrm{r}=0.835$ that is larger than critical value of table at level $99 \%(0.302)$, that shows there is a significant and direct difference at level $99 \%(\mathrm{p}<0.01)$ and with planning and organizing 
categories, respectively, with a correlation coefficient $r=0.258, r=0.235$ at level $95 \%$, has direct and significant correlation. But the correlation coefficient of philosophical mindset with assessment and mood categories respectively has $\mathrm{r}=0.216$ and $\mathrm{r}=0.220$, which statistically is not significant at the $95 \%$ level $(\mathrm{P}>0.05)$.

\section{CONCLUSIONS}

At present, the capabilities as follows are so important: the power to order things, means understanding of the relationship part issue to the whole in a vast area, Immediate programs relevance to future goals, having power to analysis information and opinions, discover the basics in every position, High flexibility, avoiding One-dimensional approach to problems, According to others, regardless of its source for the overall direction of the organization and people foe achieving their goals. These cases can be impressive for individual, social behavior, and improving organizational performance. The results obtained in this study also show that the rate of philosophical mindset of the managers in secondary school BOJNURD city has a meaningful relationship with management components. This result suggests that managers with high philosophical mindset will have a higher yield. Also, the t-test results are given in Tables 1 and 2 show that there is no significant difference between philosophical mindset and doing managerial tasks in men and women managers.

\section{Practical suggestions:}

1) What seems to be important is that researchers of educational system pay attention to dimensions of logical thinking and philosophical mindset of educational managers addition organizational and administrative aspects and for evaluation and selection of educational managers should consider these skills.

2) familiarize managers with the character of philosophical mindset through training workshops, conference and seminars to institutionalization of philosophical mindset dimensions and to demonstrate their importance in the process of improving organizational performance.

\section{References}

[1] Abutorabi, Rozita, (2008), studying the effects of philosophical mind training on organizational climate, master's thesis, Ferdowsi University of Mashhad.

[2] Amirtash,A.AlirezaAbkar,A \&Mozaffari,A.(2011), The Relationship Between Philosophic-Mindedness And Academic Performance Of Physical Education Faculty Members, World Applied Sciences Journal 15 (6): 885-889.

[3] Bowlinger, D. (2002). Philosophic mindedness level in educational managers to their employees operations in Chicago schools. [PhD Dissertation Abstract]. Irwin University. Chicago, USA.

[4] Bahari, Saifullah, (2006), the relationship between managers' philosophical mind and their performance, New ideas in Educational Sciences, first year, No. IV, pp. 45-54.

[5] Buckingham, H.A. (2006). A study of the relationship between headmasters'independent schools as perceived by teachers, Souther connectica state university New Haven, CT. 
[6] Jazayeri Naseri.N,HeidariTafreshi,Gh. N Aminimoghadamfarouj(2012) A Study Of The Relationship Between Philosophical Mindedness Of Managers And Organizational Climate In Bojnurd Schools, European Journal Of Scientific Research, Issn 1450-216x Vol.70 No.3 (2012), Pp. 450-457.

[7] Khazaei, H. (2006), studying the relationship between philosophical minds of educational managers and rate of enjoying the participation of school teachers in high schools of Ardabil, MS Thesis, Tehran University of Teacher Education.

[8] Robbins, Stephen. P., (2004), Fundamentals of Organizational Behavior, translated by Ali Parsaeian and Seyed Muhammad Aerabi, Tehran, Publications Office of Cultural Research.

[9] Ruona, Wendy E.A. \& Lurham, S.A. (2004). A philosophical framework for thought and practice in human resource development, Germany: University of Georgia.Smith, P.G. (1965). What is philosophy education?, U.S.A.: McMillan.

[10] Smith, Philip J. (1995), philosophical mind in educational administration, translated by Mohammad Reza Behrangi, Tehran: Kamale Tarbiat Publication

[11]Wilgis, M., \& McConnell, J. (2008). Concept mapping: an educational strategy to improve graduate nurses critical thinking skills during a hospital orientation program. The journal of continuing education in nursing. VO 139. No3.

[12]Zaki, Mohammed Ali, (1998), The social dimension of the philosophical mind of managers, management knowledge, Year 11, No. 44. 